\title{
The effects of higher education programme characteristics on allocation and performance of the graduates: a European view
}

Citation for published version (APA):

Heijke, J. A. M., \& Meng, C. M. (2006). The effects of higher education programme characteristics on allocation and performance of the graduates: a European view. Researchcentrum voor Onderwijs en Arbeidsmarkt, Faculteit der Economische Wetenschappen. ROA Research Memoranda No. 4E https://doi.org/10.26481/umaror.200604E

Document status and date:

Published: 01/01/2006

DOI:

10.26481/umaror.200604E

Document Version:

Publisher's PDF, also known as Version of record

Please check the document version of this publication:

- A submitted manuscript is the version of the article upon submission and before peer-review. There can be important differences between the submitted version and the official published version of record.

People interested in the research are advised to contact the author for the final version of the publication, or visit the DOI to the publisher's website.

- The final author version and the galley proof are versions of the publication after peer review.

- The final published version features the final layout of the paper including the volume, issue and page numbers.

Link to publication

\footnotetext{
General rights rights.

- You may freely distribute the URL identifying the publication in the public portal. please follow below link for the End User Agreement:

www.umlib.nl/taverne-license

Take down policy

If you believe that this document breaches copyright please contact us at:

repository@maastrichtuniversity.nl

providing details and we will investigate your claim.
}

Copyright and moral rights for the publications made accessible in the public portal are retained by the authors and/or other copyright owners and it is a condition of accessing publications that users recognise and abide by the legal requirements associated with these

- Users may download and print one copy of any publication from the public portal for the purpose of private study or research.

- You may not further distribute the material or use it for any profit-making activity or commercial gain

If the publication is distributed under the terms of Article $25 \mathrm{fa}$ of the Dutch Copyright Act, indicated by the "Taverne" license above, 
The effects of higher education programme characteristics on allocation and performance of the graduates: a European view

\author{
ROA-RM-2006/4E \\ Hans Heijke, Christoph Meng
}

Research Centre for Education and the Labour Market

Faculty of Economics and Business Administration

Maastricht University

Maastricht, October 2006 
ISBN 10: 90-5321-447-X

ISBN 13: 978-90-5321-447-3

Sec06.107.doc 


\section{Contents}

Abstract

Acknowledgments

1 Introduction 1

2 Theoretical framework 2

2.1 Discipline-specific versus academic 2

2.2 Standardization of the competencies provided 4

2.3 Exclusive entrance $\quad 6$

2.4 Integration of learning and working 6

$\begin{array}{ll}2.5 \text { Internationalization } & 7\end{array}$

3 Data 3

3.1 The three occupational domain $\quad 8$

3.2 The five education programme characteristics 8

4 Empirical Analyses 11

4.1 The empirical model 11

4.2 Results 13

4.2.1 Allocation 13

$\begin{array}{ll}\text { 4.2.2 Wages } & 17\end{array}$

5 Concluding remarks 21

References $\quad 21$

Appendix A: Education programme characteristics 25

$\begin{array}{ll}\text { Appendix B: First-stage model } & 29\end{array}$

Appendix C: Robustness Tests $\quad 35$ 



\begin{abstract}
This paper provides new insight into the role of higher educational programmes in allocation and performance during the transition from education to the labour market. Using a unique data set on the labour market situation of graduates in nine European countries, we investigate the significance of five characteristics of the higher education programmes: (1) The academic versus discipline-specific character of the competencies generated by the curriculum; (2) the level of standardization of the generated competencies; (3) the extent by which working and learning activities are combined, (4) the level of internationalization of the educational programme and (5) the extent to which a programme provides exclusive entrance to particular occupations.

First, our results reveal in particular the importance of the competence orientation of the education programme. Allocation of graduates to occupations takes place in a manner that yields a situation wherein the competence orientation of the education is in congruence with the competence orientation of the occupation. Second, we show that the standardization of the education programme with respect to the competencies students acquire plays an important role in both informing the employer, and reducing the adjustment costs. By that, it allows for a higher remuneration of the graduates.
\end{abstract}

\title{
Acknowledgments
}

We would like to thank participants at the Transition in Youth Network Conference in Madeira (2003), at the EEA conference in Madrid (2004), at the EALE conference in Lisbon (2004) and participants at seminars at the University of Barcelona (September, 2003), Maastricht University (October, 2003 and December, 2003), EIM (Zoetermeer, 2004), IAB (Nuremberg, 2004) and Bamberg University (2004) for their comments on earlier drafts of the paper. Furthermore, we benefited a great deal from comments by Jim Allen, Hans-Peter Blossfeld, Lex Borghans, Josep M. Masjuan Codina, Ben Kriechel, Ferrane Mane, Joan Muysken, Jordi Planas, José-Gines Mora Ruiz, Sybrand Schim van der Loeff, Inge Sieben, Luc Soete, Alexandra Spitz, Roy Thurik, Rolf van der Velden and Cees van der Vleuten. 



\section{Introduction}

The transition from education to the labour market is crucial. Graduates search in a labour market about which they are relatively badly informed and where jobs may be scarce. Employers try to find the most suitable higher educated candidates for their available vacancies. The process that matches heterogeneous graduates to heterogeneous jobs has received much attention in the literature (e.g. Jovanovic, 1979, 1984; Barron and Loewenstein, 1985; Topel, 1986). If this match is not perfect, costly additional learning by training and/or job experience is needed to improve or adjust the initial competencies acquired in education. Indeed, the importance of on-the-job training for improving competencies has long been emphasized (Becker, 1964; Mincer, 1974), and there have been many debates on its impact on productivity and wages (Brown, 1989; Lynch, 1992; Acemoglu and Pischke, 1998; Pischke, 2000). In addition to the applicants' educational backgrounds and performances, employers know relative little about their specific productive capacities. Mismatches between desired and realized allocation over jobs and between expected and realized performance in these jobs may occur easily.

Given this context, employers may be expected to rely not only on individual characteristics of the applicant, but also on characteristics of the education programme, and hence on group features, to retrieve relevant information for hiring and/or salary decisions. To increase the knowledge on this point, we will address in this paper the extent to which typical characteristics of higher education programmes are valued, as they either reveal the productive capacities taught to the students or as they reduce the uncertainty with respect to the type and level of competencies which the individual graduates possess. In both cases, the risk of high adjustment costs is reduced.

Most of the existing comparative research on the impact of educational characteristics on labour market outcomes focuses on secondary education level systems. In particular, authors considered the extent to which vocational training at this educational level is provided and the extent to which secondary education programmes within a country are standardized and stratified (see e.g. Allmendinger, 1988; Müller and Shavit, 1998; Maurice, Sellier and Sylvestre, 1982; Hannan, Raffe and Smyth, 1996). Notwithstanding their relevance for the school-to-work transition, the general focus on secondary education and their analyses on system level restricted these earlier approaches greatly. With an increasing proportion of the young Western population continuing their education into tertiary level, we are in need for indicators extending the range into tertiary education programmes and encompassing signals that these programmes provide to the labour market.

Accordingly, a first line of research looked at the impact of the field of study on labour market success. Generally, this research argued that the field of study mediates the link between higher education participation and educational outcome (see e.g. Berger, 1988a, 1988b; James, Alsalam, Conaty and To, 1989; Rumberger and Thomas, 1993; Müller, Steinmann and Ell, 1998; van de Werfhorst, 2002; Kim and Kim, 2003; Finnie and Frenette, 2003). However, the simple use of the higher education qualification (or field of study name) is a far from ideal indicator of the competencies actually acquired in higher education or used in the labour market (see e.g. Ashton and Green, 1996; Meng, 2006).

To enrich our knowledge on the role of the education programme on the transition of graduates to the labour market, this paper intends, at least partially, to open the black box 
'field of study'. We do so by considering five characteristics of education programmes that are normally hidden in this black box. By that, we aim to reveal the effectiveness with which higher education programmes allocate their graduates over various occupational domains in the labour market and how these graduates perform in the occupation obtained. The first three characteristics (discipline-specific versus academic competencies orientation; standardization with respect to competencies and providing exclusive entrance to certain occupations) consider the type and level of competencies taught to the students. The fourth and fifth characteristic (integration of working and learning; internationalisation of programme) deal with experience outside the regular teaching process and competencies acquired in this context. In order to trace the effects of these programme characteristics, we look at the labour market from the perspective of a particular education programme. More precisely, three occupational domains are distinguished: (1) A domain in which optimal fulfilling of the tasks requires graduation, and hence the discipline-specific competencies, of a particular programme, (2) a domain in which discipline-specific competencies of another education programme offer a comparative advantage, and (3) a domain in which graduation from a particular higher education programme is not a direct requirement and hence academic competencies are demanded.

The structure of the paper is as follows. Section 2 discusses the theoretical framework. Section 3 presents the data used in this chapter. The econometric model is developed in Section 4. First, we will evaluate the impact of the education programme characteristics on allocation. Second, the influence of the education programme characteristics on the wage will be investigated. Section 5 concludes the paper.

\section{Theoretical framework}

\subsection{Discipline-specific versus academic}

To relate educational programme characteristics to labour market outcomes, we take job heterogeneity into account. We thereby follow Lazaear (2003) and characterize occupational domains according to the level and set of discipline-specific and academic competencies employees working in these occupational domains have to possess:

(1) $C_{j}=C\left(\bar{D} \bar{S}_{s}, A\right)$

where $C_{j}$ is the competencies set of employees in occupational domain $j, \bar{D} \bar{S}_{s}$ a vector of types of discipline-specific competencies the employees have to possess, and $A$ the level of academic competencies ${ }^{1}$ the employees have to possess. Assuming for reasons of simplicity that the set of required competencies in an occupational domain consists of a

1. We will not add an index (s) to term $A$ reflecting the field of study in which they are acquired, as we assume academic competencies to be transversal. Hence, the term 'academic' does not refer to elements common to different discipline-specific competencies but to the additional subjectindependent content of these competencies (for a more detailed discussion on this point, see Meng, 2006). 
linear combination of a package of discipline-specific competencies and of academic competencies, we can write:

(2) $C_{j}=\eta_{j} *\left[\sum_{s=1}^{n}\left(\mu_{s}^{*} D S_{s}\right)\right]+\left(1-\eta_{j}\right) * A \quad$ with $\sum_{i=1}^{n} \mu_{s}=1$ and $0 \leq \eta_{j}, \mu_{s} \leq 1$

Equation 2 implies that the mix of competencies employees in a particular occupational domain $j$ must possess is given by the sum of discipline-specific competencies (DS) of the different types $s$ and the level of academic competencies $(A)$. The term $\mu_{s}$ measures the weight given to a particular type of discipline-specific competencies in the package of discipline-specific competencies, while the term $\eta_{j}$ reflects the weight given to the whole package of discipline-specific competencies.

Taking the type of discipline-specific competencies that is central to the study the graduates have followed $(s=m)$ out of the vector of discipline-specific competencies we write:

(3) $\left.C_{j}=\eta_{j} *\left[\mu_{s=m} * D S_{s=m}+\left(1-\mu_{s=m}\right) \sum_{s=1}^{n} D S_{s \neq m}\right)\right]+\left(1-\eta_{j}\right) * A$

Based on these assumptions, we then define the sets of competencies that provide the graduates with a comparative advantage in a particular occupational domain. More in specific, and from the perspective of the graduates from a specific education programme $(s=m)$, we define three occupational domains. (1) The own discipline-specific competencies domain that combines jobs where the education programme followed is the appropriate preparation for. (2) The discipline-specific competencies domain of another education programme that combines jobs for which another education programme offers the appropriate preparation. To possess a comparative advantage in this domain, the disciplinespecific competencies of graduates from programme $m$ must either be strong transferable and/or their level of academic competencies must allow them to acquire the disciplinespecific competencies useful in these occupations quickly by on-the-job training or simply by learning-by-doing. (3) The academic competencies domain that consists of occupations in a market segment that is characterized by a less strong link between occupations and a particular education programme. The focus of attention in this market segment is on academic competencies rather than on a particular type of discipline-specific competencies. This does not a priori imply that discipline-specific competencies are not important in this domain, but rather that either the discipline-specific competencies required in this domain are less likely to be acquired in higher education or that they are so new that they have not yet been incorporated in the higher education programmes. In terms of equation (3) the sets of competencies providing a comparative advantage in these domains is given as follows:

(1) The own discipline-specific competencies domain in case of:

$$
\eta_{j}>1-\eta_{j} \text { and } \mu_{s=m}>1-\mu_{s=m}
$$


(2) The discipline-specific competencies domain of another education programme in case of:

$\eta_{j}>1-\eta_{j}$ and $\mu_{s=m}<1-\mu_{s=m}$

(3) The academic competencies domain in case of:

$\eta_{j}<1-\eta_{j}$

Considering the above setting, structuring the education programme towards a particular outcome with respect to the acquired set of competencies might strongly influence the graduates transition from higher education to the labour market. Structuring the education programme towards a planned learning outcome of discipline-specific competencies ${ }_{2}$ and hence perceiving the role of academic competencies solely as the means by which the learning of discipline-specific competencies is enhanced rather than an end in itself, provides the graduates on average with a relatively greater share of discipline-specific competencies. To the extent that these competencies have a direct productive application value in occupations closely linked to the education programme completed $\left(\mu_{s=m}>1-\mu_{s=m}\right)$, we may expect these graduates to have a greater probability of finding their way into the own discipline-specific competencies domain (see also Heijke, Meng and Ris, 2003). Furthermore, we may expect these graduates to have a relatively greater comparative advantage when matched to an occupation in the own discipline-specific domain but a relative greater loss in the application of their discipline-specific competencies in other cases.

Structuring the education programme towards a planned learning outcome of academic competencies provides the graduates on average with a relatively greater share of academic competencies. These programmes use the acquisition of discipline-specific competencies as the material needed to enhance the acquisition of academic competencies. The non-contextbound characteristics of academic competencies can be applied in a wide range of occupations and hence it is expected to find a more dispersed allocation of these graduates across the different occupational domains distinguished, with a tendency towards the academic competencies domain. Moreover, the allocation dependence of the wages is expected to be less.

\subsection{Standardization of the competencies provided}

In a world of complete and freely available information, employers can be expected to search for graduates who offer a mix of competencies resembling as closely as possible the mix of competencies required to optimize performance of their tasks. Conversely, graduates search for these occupations to maximize their wage rates. Unfortunately, the matching of higher education graduates to vacancies in the labour market does not take place in such a perfect world. In spite of an accurate perception of their competencies, characteristics and possibilities, graduates have only a vague notion of the exact working requirements. Similarly, employers, knowing what the working requirements are, are relative badly informed as to what extent the characteristics of the graduates match the requirements. Given this asymmetric distribution of information and its private character, employers face a time-consuming and costly evaluation of an applicant's productivity. In this sense, the 
standardization of education programmes with respect to the competencies taught can be an important cost-determining factor.

Let us assume that both the graduates' level of discipline-specific competencies and the level of academic competencies acquired in higher education are not perfectly measurable during the application procedure. More precisely, we can write:

(4) $D S_{i, s}^{e}=D S_{i, s}+\delta_{D S s}$

(5) $A_{i}^{e}=A_{i}+\delta_{\text {As }}$

where $D S_{i, s}^{e}$ and $A_{i}^{e}$ are the revealed level of discipline-specific competencies of type $s$ (indicating the higher education programme graduated from) and academic competencies of applicant (i), respectively, $D S_{i, s}$ and $A_{i}$ are the real level of discipline-specific and academic competencies acquired by the graduate, respectively, and $\delta_{D S s}$ and $\delta_{A s}$ the measurement error unknown to the employer, assumed to be normally distributed around zero.

Equation (4) and (5) imply that graduates, after having been selected for an occupation, may reveal productive capabilities above or below the level initially measured. Both situations, a productivity lower or a productivity higher than the targeted one, may be regarded as undesirable by the employer, as they involve further costs at least partially to be born by him. If actual productivity is lower than targeted, the employer faces the decision between continuing the work contract and ending it. In the first case, the employer needs to invest in employee training. In the second case, he needs to restart the costly search process for a more suitable candidate. If actual productivity is higher than targeted, the employer may first profit from the situation. But he will be confronted to an increasing extent with an unsatisfied employee, who either demands higher wages or quits the job and forces the employer to restart the costly search for a new candidate.

A reduction in the measurement error is beneficial both for the employer, as it reduces the expected costs involved in hiring a graduate, and for the graduate, as it increases the wages offered. To address this problem, employers may prolong the application procedure and run more tests, or rely on information gathered through experience or accessed externally. In the latter case, the importance attached to the group membership of the graduate, as a source of conveying information with respect to the individual graduate, increases. The more homogeneous the group of students graduating from a particular education programme, the more information their group membership reveals about the individual graduate. In our case, a strong index ${ }^{2}$ for this homogeneity is the standardization of an education programme with respect to the level of discipline-specific competencies or the level of academic competencies. The more standardized an education programme, the less variation between graduates' levels of competencies and hence the smaller the expected measurement error. A smaller measurement error will then reduce the adjustment costs. The answer to the question if employers/graduates profit more from a standardization

2. We follow Spence (1973) and refer to observable attributes (which cannot be altered by the graduate) as indices, reserving the term signals for observable characteristics attached to the individual that are subject to manipulation by him. 
of discipline-specific competencies or from the standardization of academic competencies is related to the importance attached to one of the two competencies in the occupation to which the graduate is matched.

\subsection{Exclusive entrance}

Our third characteristic concerns the fact that certain education programmes provide an exclusive possibility to enter certain labour market occupations. This holds in particular for law and health science studies. To be employed as a lawyer, one has to graduate in law and to be employed as surgeon, a medical study is a prerequisite. This guarantees employers and potential customers that the job holder has the necessary competencies to fulfil the tasks. Considering our intention to analyze the allocation of graduates over different occupational domains, this characteristic can undoubtedly be regarded as important.

\subsection{Integration of learning and working}

The increasing importance of knowledge in society and economy, and the implied shift from the importance of a classical scientific knowledge structure in disciplines towards specific contextualized knowledge (Hövels, 2003) stimulate larger interactions between learning in the classroom and economic life. In an economy in which knowledge capital adds more value than classical factors, such as physical capital, raw materials and physical labour, it seems less and less useful to distinguish between exclusive classroom education and learning that takes part outside the classroom (see e.g. Kessels, 1998). Higher education cannot afford to take a passive stand, but should initiate possibilities for cooperative education, providing opportunities for connecting the traditional higher university campus to the work environment. This helps students to acquire competencies "that are difficult to acquire in the traditional university lecturing room, such as communication skills, the ability to work together in a team and being comfortable in a work environment" (Kessels and van Wijngaarden, 2003).

Strengthening the link between classroom teaching and direct acquisition of working experience imposes a trade-off between time spent on classical teaching of competencies and time spent on generating work habits and out-of-classroom competencies, contributing to a smooth integration of graduates into their first occupation. Co-op education not only enables graduates to apply their theoretical knowledge to real working situations, but also to take the new information and extended knowledge back to the classroom. Moreover, contacts established between employers and students and the information transfer taking place may help solve the information asymmetry during the transition period.

The strongest positive effects of co-op education can be expected for graduates who have actively participated in work placements or internships. However, the set-up of a co-op education programme can produce positive spillover effects for non-participating peers. First of all, stimulating and providing students with possibilities of internships or work placements outside the campus, generally goes hand in hand with structuring the curriculum itself in a more practically oriented way, allowing the two-way transfer of knowledge by graduates to be maximized. Second, non-participants may benefit at the time of graduation from the nonexclusive network with employers established by the educational institute they attended. 
Firms may contact lecturing staff with information on vacancies or firms may generally prefer students from a particular programme due to good experience with interns of this programme.

\subsection{Internationalization}

Contacts with foreign partners or customers have become the daily work of a large number of employees. Not surprisingly, we can see in the labour market a growing demand for graduates with knowledge of international affairs, international economics, international law or more generally, with the knowledge of foreign languages and cultures. In recent years, the internationalization of economic life is being reflected more and more in the internationalization of education. An increasing number of higher education students complete part of their studies in a foreign country. Moreover, education at home gets more and more internationalized by, for example, teaching part of the courses in a foreign language. The confrontation of graduates with this internationalization of education programmes may have its impact on the level of competencies of all graduates of the programme (see Meng, 2006). However, it may be of even more importance that it broadens the horizon with which graduates enter the labour market. As the labour market increasingly asks for "international" graduates, we expect the return to this asset to be positive.

\section{Data}

The research data for this paper are obtained from a European wide postal survey among 1994/1995 higher education graduates carried out in $1998 .^{3}$ The data provide, among a whole set of personal characteristics and the knowledge, skills and attitudes possessed at time of graduation, a rich set of information with respect to the study programme followed. In particular, the data allow us to analyze the labour market outcome of roughly 18500 higher education graduates in nine European countries (Austria, Finland, France, Germany, Italy, Norway, Spain, the Netherlands and United Kingdom) covering 14 types of higher education institutions. To control for differences between programmes of different higher education institutions in a country, we distinguish in France between university and Grande Écoles programmes, in Germany between university and Fachhochschulen programmes, in the Netherlands between university and higher vocational education programmes, in the United Kingdom between old and new universities, and in Norway between university and university colleges programmes. In Spain, Italy, Austria and Finland, no distinction is made. Although in Austria and Finland Fachhochschulen and Polytechnics, respectively, were introduced in the mid-1990s, the data used here do not cover graduates from these higher education institutions. Considering our focus on education programmes and their characteristics, a first best approach would be to analyze narrowly defined education programmes, and to distinguish between the institutes offering these programmes. Unfortunately, the data does not allow for such a first best approach and forces us to use a

3. CHEERS survey: Careers after Higher Education: a European Research Study. For further information, see http://www.uni-kassel.de/wz1/tseregs.htm. 
second best approach. We therefore aggregated over institutes in a particular higher education institution (e.g. university type higher education in the Netherlands) and over narrowly defined study programmes. For the latter, we made use of the information on the individuals' educational field provided by the International Standard Classification of Education (ISCED 3 digits). We recoded the 3-digit ISCED into 7 education fields, namely 'arts and humanities', 'social sciences', 'business', 'law', 'natural sciences', 'engineering' and 'health sciences'. Concluding, the data allows us to distinguish between a total of 91 different higher education programmes nested in 14 higher education institutions and nine countries.

\subsection{The three occupational domain}

In Section 2, we proposed a division of occupations into three occupational domains, namely a domain in which optimal fulfilling of tasks requires graduation, and hence discipline-specific competencies of a particular programme, a domain in which disciplinespecific competencies of another education programme offer a comparative advantage, and a domain in which in particular academic competencies are demanded. To group the graduates' occupations, we relied on the following question in the survey: "How would you characterize the relationship between your field of study and your area of work?" We assumed that the graduate worked in the own discipline-specific competencies domain if he answered that either "my own field of study is the only/best preparation" or "a related field could as well prepare." Graduates were assumed to work in the discipline-specific competencies domain of another programme if they answered that "another field would have been more useful." Lastly, graduates were assigned to the academic competencies domain if they indicated that "the field of study does not matter very much." Overall, a clear majority of graduates worked in their own discipline-specific competencies domain $(75 \%)$, approximately $10 \%$ work in the domain of another education programme, and $15 \%$ in the academic competencies domain.

\subsection{The five education programme characteristics ${ }^{4}$}

\section{Competence orientation of the programme}

To measure the discipline-specific competence orientation of the education programme, we have used the information in the data set with respect to different competencies, representing demands for and supplies of knowledge. Graduates were asked to indicate on a five-point scale, ranging from 1 ('not at all') to 5 ('to a very high extent'), the extent to which they had a given competency at the time of graduation. Using a hierarchical clustering method, we retained two clusters of competencies representing best the idea of academic and discipline-specific competencies needed to measure the discipline-specific competence orientation of the programme. ${ }^{5}$ The two clusters consist of the following individual items:

4. The figures for the five educational programme characteristics are presented in Appendix A.

5. For a detailed discussion on the clustering method used, an overview of some descriptives with respect to the level of academic and discipline-specific competencies acquired by higher education graduates and required in the labour market, as well as for a discussion on the validity of the two constructs, please see Meng, 2006. 


\section{Academic competencies}

Learning abilities

Reflective thinking, assessing one's own work

Problem-solving abilities

Analytical competencies

Documenting ideas and information

\section{Discipline-specific competencies ${ }^{6}$}

Field-specific theoretical knowledge

Field-specific knowledge of methods

First, we calculated the mean score of the competence clusters possessed the time of graduation per education programme. Second, we calculated the difference between the level of discipline-specific competencies and the level of academic competencies that an education programme provides to its graduates. ${ }^{7}$ Hence, the competence orientation of a particular programme can range from -4 (extremely academically oriented) to 4 (extremely discipline-specifically oriented). The difference between the acquired level of disciplinespecific competencies and the acquired level of academic competencies can then be used as a proxy of the degree of comparative advantage in a particular occupational domain a graduate possess. On average, the education programmes scored slightly academically oriented (average of -0.05 ). Moreover, there is a strong country effect with programmes in Austria, Germany, the Netherlands and Norway scoring strikingly more discipline-specifically oriented than programmes in the other countries. However, the relative ranking of an education programme is quite similar across the fourteen higher education institutions.

\section{Standardization}

The standardization of an education programme was introduced as a measurement for the homogeneity of the graduates with respect to the competencies obtained during their studies. A simple way of measuring this was given by the variance of the discipline-specific competencies acquired by the graduates of a particular education programme and by the variance of the academic competencies: The smaller the variance the higher the standardization. Being unaware of the institute concerned, it was necessary to be careful not to measure the variation between institutes but, as far as possible, the variation related to the heterogeneity between graduates. For this reason, we controlled with ANOVA analyses for possible variance effects between institutes and extracted the variance between graduates. To simplify the reading of the results, we then subtracted the variance from 1 . The

6. Unfortunately, the data allow us only to measure the discipline-specific competencies of the study programme followed and not any other type of discipline-specific competencies acquired

7. The reason for not just simply taking the average level of discipline-specific competencies and the average level of academic competencies separately in the analyses, is that graduates in particular countries or in particular higher education institutions can be expected to score high (low) on both clusters depending on the extent of self-criticism. Using the difference between the two scores was a possible way to circumvent the problem of possible bias in the level of reported competencies. 
'standardization' figures (see Appendix A) indicate that, on average, graduates are more homogeneous with respect to academic competencies than with respect to disciplinespecific competencies.

\section{Exclusive entrance}

The third characteristic is based on the fact that certain education programmes exclusively offer entrance to certain labour market occupations. This holds in particular for studies in 'law' and 'health sciences'. To control for this in the empirical analyses, we explicitly used a dummy indicating whether the respondent graduated from either of these two fields of study.

\section{Work-learning relation}

The data contains different questions with respect to the work-learning relation of the programme. Graduates were asked to indicate if they have completed an internship/work placement during their study as part of their degree course and were also asked to rank their programme with respect to the importance given to the direct acquisition of working experience. To circumvent the problem of cultural bias with respect to the second question and the problem that graduates might rank their programme depending on the extent to which their expectations were fulfilled, we used the percentage of graduates that took part in an internship/work placement as a measure for the extent of co-op education.

Table 1

Correlation between programme characteristics

\begin{tabular}{|c|c|c|c|c|c|}
\hline $\begin{array}{l}\text { Discipline- } \\
\text { specific } \\
\text { competence } \\
\text { orientation }\end{array}$ & $\begin{array}{l}\text { Standardization } \\
\text { of discipline- } \\
\text { specific } \\
\text { competencies }\end{array}$ & $\begin{array}{l}\text { Standardization } \\
\text { of academic } \\
\text { competencies }\end{array}$ & $\begin{array}{c}\text { Work-learning } \\
\text { relation }\end{array}$ & $\begin{array}{l}\text { Internatio- } \\
\text { nalization }\end{array}$ & $\begin{array}{c}\text { Exclusive } \\
\text { entrance }\end{array}$ \\
\hline
\end{tabular}

\begin{tabular}{|c|c|c|c|c|c|c|}
\hline $\begin{array}{l}\text { Discipline-specific } \\
\text { competence orientation }\end{array}$ & 1 & $0.42^{* * *}$ & 0.064 & $0.32^{* * *}$ & 0.04 & 0.06 \\
\hline $\begin{array}{l}\text { Standardization of } \\
\text { discipline-specific } \\
\text { competencies }\end{array}$ & & 1 & $0.41^{* * *}$ & $0 . .29^{* \star *}$ & 0.03 & 0.15 \\
\hline $\begin{array}{l}\text { Standardization of } \\
\text { academic } \\
\text { competencies }\end{array}$ & & & 1 & $0.22^{* *}$ & 0.18 & 0.17 \\
\hline Work-learning relation & & & & 1 & 0.18 & 0.00 \\
\hline Internationalization & & & & & 1 & -0.09 \\
\hline Exclusive entrance & & & & & & 1 \\
\hline
\end{tabular}

Note: ${ }^{* * /{ }^{* *}}$ correlation is significant at a $1 \% / 5 \%$ level. Number of programmes included: 91

\section{Internationalization}

The final education programme characteristic was the international orientation of the education programme. The only possible indicator provided by the data was the percentage of graduates that completed part of their study programme abroad.

Concluding this section, Table 1 reports on the correlation between the five programme characteristics. The results show that there are, in particular, positive relations between the 10 
discipline-specific competence orientation, the standardization of discipline-specific competencies, the standardization of academic competencies and the work-learning relation.

\section{Empirical Analyses}

\subsection{The empirical model}

Our objective was to relate differences with respect to the allocation outcome of graduates across the three occupational domains and with respect to the wage rates paid to higher education programme characteristics. As these characteristics vary across the education programmes, but are by construction constant among the graduates belonging to the same programme, including them jointly in an estimation with individual characteristics ignores the possible stochastic properties of the parameters at the education programme level and is likely to bias the estimation results and the error term (see Moulton, 1986). To address this problem, we followed Card and Krueger (1992), Heckman, Layne-Farrar and Todd (1996) and Case and Yogo (1999) and applied a two-stage procedure. ${ }^{8}$ In the first stage, we estimated differences in the allocation outcome and wage rate between graduates from different education programmes. We estimated these effects with a fixed-effects model, and hence did not allow the individual covariates to differ according to the country or the higher education institutions from which the respondent graduated. We will return to this assumption in Appendix $C$ when the model is tested for robustness. In the second stage, we regressed these 'fixed effects' on the programme characteristic indicators. In more detail, the empirical approach for allocation and income looks as follows.

\section{Allocation}

As there is, a priori, no explicit order between the three labour market domains discerned, we used in the first stage a multinomial logit model, which provided fixed effects for the education programmes comparing the probabilities of being allocated to an occupation inside a particular domain ("the domain of another programme" or the "academic competencies domain") with the probabilities of being allocated to an occupation in the reference domain ("the own discipline-specific competencies domain"). Formally, the model makes it possible to compute the log-odds ratios as follows:

(6) $\ln \left[\frac{P_{i d}}{P i(d=0)}\right]=\alpha_{d}+S_{m} * \gamma_{m d}+X_{i} * \beta_{d}+\varepsilon_{i d}$

where $d=0,1,2$ indicates respectively the own discipline-specific competencies domain, the domain of another education programme and the academic competencies domain, $P_{i d}$ is the probability that individual $i$ is allocated to an occupation inside domain $\mathrm{d}, P_{i(d=0)}$ is the

8. According to Card and Krueger (1992), this approach provides a convenient reduction of the data and facilitates highly general models of, for example, the earnings function. Moreover, Heckman, Layne-Farra and Todd (1996) stated that this model has the 'beauty' of being derivable from a 'richly interpretable economic model of how quality affects earnings' (p. 599). 
probability that individual $i$ is allocated to an occupation in the reference domain, $a$ a constant, $S_{m}$ are the dummies for the education programmes $m, X_{i}$ is a matrix of variables characterizing individual $i$, and $\beta_{d}$ and $\gamma_{m d}$ are row vectors of coefficients for occupational domain category $d$. To control the programme effects from influences on the individual level, we included as covariates the age of the respondent, gender, dummies for the pre-higher education grades, the socio-economic background of the student, the level of academic competencies, the level of discipline-specific competencies, dummies for internships and work placements, a dummy for spending part of the study in a foreign country, the selfreported level of adaptability, the importance given to the use of the competencies acquired in higher education and the family situation at the time of graduation. In the second stage, we regressed the fixed effects $\left(\gamma_{\mathrm{dm}}\right)$ on the indicators discerned. ${ }^{9}$

(7) $\quad \gamma_{m d}=\delta_{d}+M_{m} * \phi_{d}+H_{u} * \eta_{d}+\psi_{d m}$

where $\gamma_{m d}$ is the fixed-effects log-odds ratios of the first stage, $M_{m}$ a vector comprising the five education programme characteristics, $H_{u}$ a vector with dummies identifying the higher education institutions graduated from (e.g. Dutch university) and $\psi_{d m}$ an i.i.d. error term.

\section{Wage}

The setup of the wage analyses is analogous to the allocation model approach. First, we estimated the education programmes' fixed-effects on wage rates, and second, we related these findings to the education programme characteristics. To take into consideration that the individual, as well as the education programme characteristics, might have different impacts, depending on the occupational domain in which the graduate worked, we estimated the wage analyses for each of the three occupational domains separately. ${ }^{10}$

(8) $Y_{i d}=\omega_{d}+S_{m} * v_{m d}+Z_{i d} * \kappa_{d}+\varsigma_{i d}$

where $Y_{i d}$, is the log hourly wage rate paid to graduates in occupational domain $0,1,2$, $\omega_{d}$ a constant, $S_{m}$ are the dummies for the education programmes, $Z_{i}$ is a matrix of variables characterizing individual $i$ and of his job and $\varsigma_{i d}$ an i.i.d. error term. As covariates on an individual/occupational level, we included the age of the respondents, gender, dummies for

9. Because the fixed effects that we tried to explain in the second stage regression were estimated coefficients, we weighted the least square regressions in the second stage by the inverse sampling variance of the first stage to take the preciseness of the first stage estimation into account.

10. Although there is a substantial amount of literature on possible unobserved selection bias through variables influencing both allocation and wages (Heijke, Meng and Ris, 2003), we assumed that unobserved variables in the allocation model were not correlated with the rate of return conditional on the other variables in the equation. We made this assumption to keep the estimation tractable, and because we focused on educational programme characteristics, which are unobservables in most studies of the return to education. 
the pre-higher education grades, the socio-economic background of the student, a dummy for having children, dummies for internships and work placements, a dummy for spending part of the study in a foreign country, the competence mismatch between the required and the acquired level, dummies for educational level mismatches, the tenure inside the occupation, dummies indicating part-time and permanent jobs, a dummy for private employers, a dummy indicating whether the graduate completed additional on-the-job training, the size of the firm and dummies for 16 different economic sectors.

Since we are interested in the way in which the discerned programme characteristics influence the wage of graduates in a particular domain, we rewrote in the second stage $v_{m d}$ as an equation in which these characteristics were included:

$$
v_{m d}=\chi_{d}+M_{m} * \theta_{d}+H_{u} * \xi_{d}+\tau_{m d}
$$

where $v_{m d}$ represents the domain-specific fixed effects of the education programmes on the wage rate, $M_{m}$ a vector comprising the education programme characteristics, $H_{u}$ a vector with dummies identifying the higher education institutions graduated from (e.g. Dutch university) and $\tau_{m d}$ an i.i.d. error term. ${ }^{11}$

\subsection{Results}

\subsubsection{Allocation $^{12}$}

The first-stage estimation yields the fixed effects of the education programmes that we intend to analyze in this section. Appendix B reports on the first-stage estimation findings and provides the fixed effects found in it. We will first discuss the findings on the probability of working in the occupational domain of another education programme relative to the probability of working inside the own education domain. Next, we will address the relative probability of working in the academic competencies domain versus the own education domain. Lastly, we will provide a combined discussion.

Table 2 presents findings of a series of regression models fitted to the estimated differences in the odds ratios comparing the probability of being matched to an occupation inside the domain of another education programme with the probabilities of being matched to an occupation inside the own discipline-specific domain. All models include not only the education programme characteristics, but also unrestricted dummies for the 14 higher education institutions distinguished, and a constant. Model 0 , the baseline model, only includes dummies for the higher education institutions. Thereafter, the education programme

11. Comparably to equation 11 , we used weighted least square to estimate 12 .

12. We tested to what extent the results for the allocation model were influenced by not being able to control for the fact that graduates not working inside their own education domain might also be more likely to work below their education level. Restricting the analysis to graduates working at least on a higher education level did not qualitatively change the results presented in this paper (data not shown). 
characteristics are first introduced individually in Models 1 through 7, and second, jointly in Model 8. Tests with respect to the linearity in the estimated relation established that only for the discipline-specific orientation, the inclusion of the square measurement increased the fit.

Table 2

Impact on the relative probability to work in domain of another education programme versus own disciplinespecific domain (standard errors in brackets)

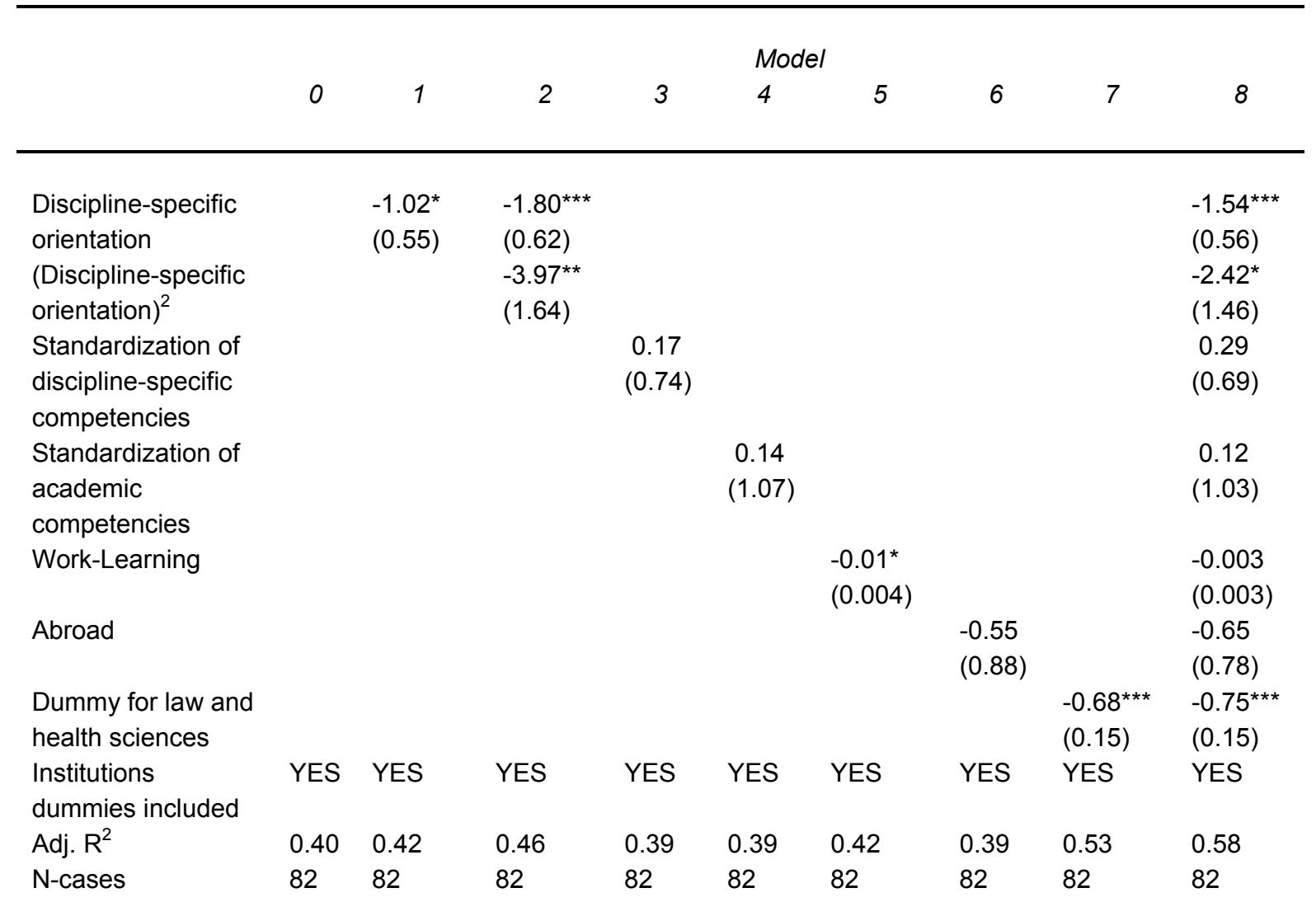

Note 1: All models further include an unrestricted constant and were estimated using WLS with the inverse sampling variance as weight

Note 2: ${ }^{* * *}$ significant at $1 \%$ level, ${ }^{* *}$ significant at $5 \%$ level, * significant at $10 \%$ level

Entering the variables individually, we found that three characteristics, namely the discipline-specific orientation (and its square), the work-learning relation and the dummy for the 'special' programmes of law and health science showed a significant correlation with the dependent variable. When entered jointly, the discipline-specific orientation and the dummy for the 'special' programmes keep their significance while the work-learning relation loses it. Whereas the 'special' programmes effect simply proves the existence of borders around occupations in the health and law sectors ${ }^{13}$, the impact of the competence orientation is of more interest. Graduates from both extreme types of course design, either highly academic or highly discipline-specifically oriented, have a decreased probability of working inside the domain of another education programme. we will return to this finding when discussing the results with respect to fixed effects of the probability of working in the academic competen-

13. Distinguishing in the models between the health and the law sectors does not qualitatively change the findings. 
cies domain relative to working in the own education domain. No impact was found for the internationalization indicator and the standardization indicators.

Table 3

Impact on the relative probability of working in academic competencies domain versus own discipline-specific domain (standard errors in brackets)

\begin{tabular}{|c|c|c|c|c|c|c|c|c|c|}
\hline & \multicolumn{9}{|c|}{ Model } \\
\hline & 0 & 1 & 2 & 3 & 4 & 5 & 6 & 7 & 8 \\
\hline Discipline-specific & & $-1.44^{\star *}$ & $-2.06^{\star \star *}$ & & & & & & $-1.08^{*}$ \\
\hline orientation & & $(0.57)$ & $(0.65)$ & & & & & & $(0.58)$ \\
\hline $\begin{array}{l}\text { (Discipline-specific } \\
\text { orientation) }^{2}\end{array}$ & & & $\begin{array}{l}-2.59^{*} \\
(1.38)\end{array}$ & & & & & & $\begin{array}{c}0.48 \\
(1.23)\end{array}$ \\
\hline $\begin{array}{l}\text { Standardization of } \\
\text { discipline-specific } \\
\text { competencies }\end{array}$ & & & & $\begin{array}{l}0.64 \\
(0.86)\end{array}$ & & & & & $\begin{array}{l}0.13 \\
(0.77)\end{array}$ \\
\hline $\begin{array}{l}\text { Standardization of } \\
\text { academic } \\
\text { competencies }\end{array}$ & & & & & $\begin{array}{c}0.48 \\
(1.21)\end{array}$ & & & & $\begin{array}{l}-0.14 \\
(1.11)\end{array}$ \\
\hline Work-Learning & & & & & & $\begin{array}{l}-0.01^{*} \\
(0.005)\end{array}$ & & & $\begin{array}{l}-0.003 \\
(0.004)\end{array}$ \\
\hline Abroad & & & & & & & $\begin{array}{c}0.61 \\
(1.01)\end{array}$ & & $\begin{array}{l}-0.55 \\
(0.81)\end{array}$ \\
\hline $\begin{array}{l}\text { Dummy for law and } \\
\text { health sciences } \\
\text { Institutions }\end{array}$ & & & & & & & & $\begin{array}{l}-1.05^{\star \star *} \\
(0.16)\end{array}$ & $\begin{array}{l}-1.07^{* \star *} \\
(0.18)\end{array}$ \\
\hline dummies included & YES & YES & YES & YES & YES & YES & YES & YES & YES \\
\hline Adj. $R^{2}$ & 0.36 & 0.39 & 0.42 & 0.36 & 0.35 & 0.37 & 0.35 & 0.62 & 0.62 \\
\hline $\mathrm{N}$-cases & 86 & 86 & 86 & 86 & 86 & 86 & 86 & 86 & 86 \\
\hline
\end{tabular}

Note 1: All models further include an unrestricted constant and were estimated using WLS with the inverse sampling variance as weight

Note 2: ${ }^{* * *}$ significant at $1 \%$ level, ${ }^{* *}$ significant at $5 \%$ level, ${ }^{*}$ significant at $10 \%$ level

Let us turn now to the fixed effects of the probability of working in the academic competencies domain relative to working in the own education domain. Table 3 reports on the second-stage results.

Entering the indicators individually, the competence orientation of the programme, the work-learning interaction and the dummy for the law and health sectors had a significant impact on the relative probability. Considering the work-learning co-operation, we can see that the results confirm the expectation that co-op education provides an closer link to occupations inside the own discipline-specific competencies domain. However, when entered jointly, the work-learning indicator loses its significance. Moreover, Model 8 reveals that, in contrast to the results presented in Table 2, the relation between the competence orientation and the outcome is purely linear. Hence, graduates from academic-competencies-oriented programmes have an increased probability of being matched to an occupation inside the academic competencies domain where their central competencies are of high value. 
Change in probability of being matched to relative to being matched to own education domain

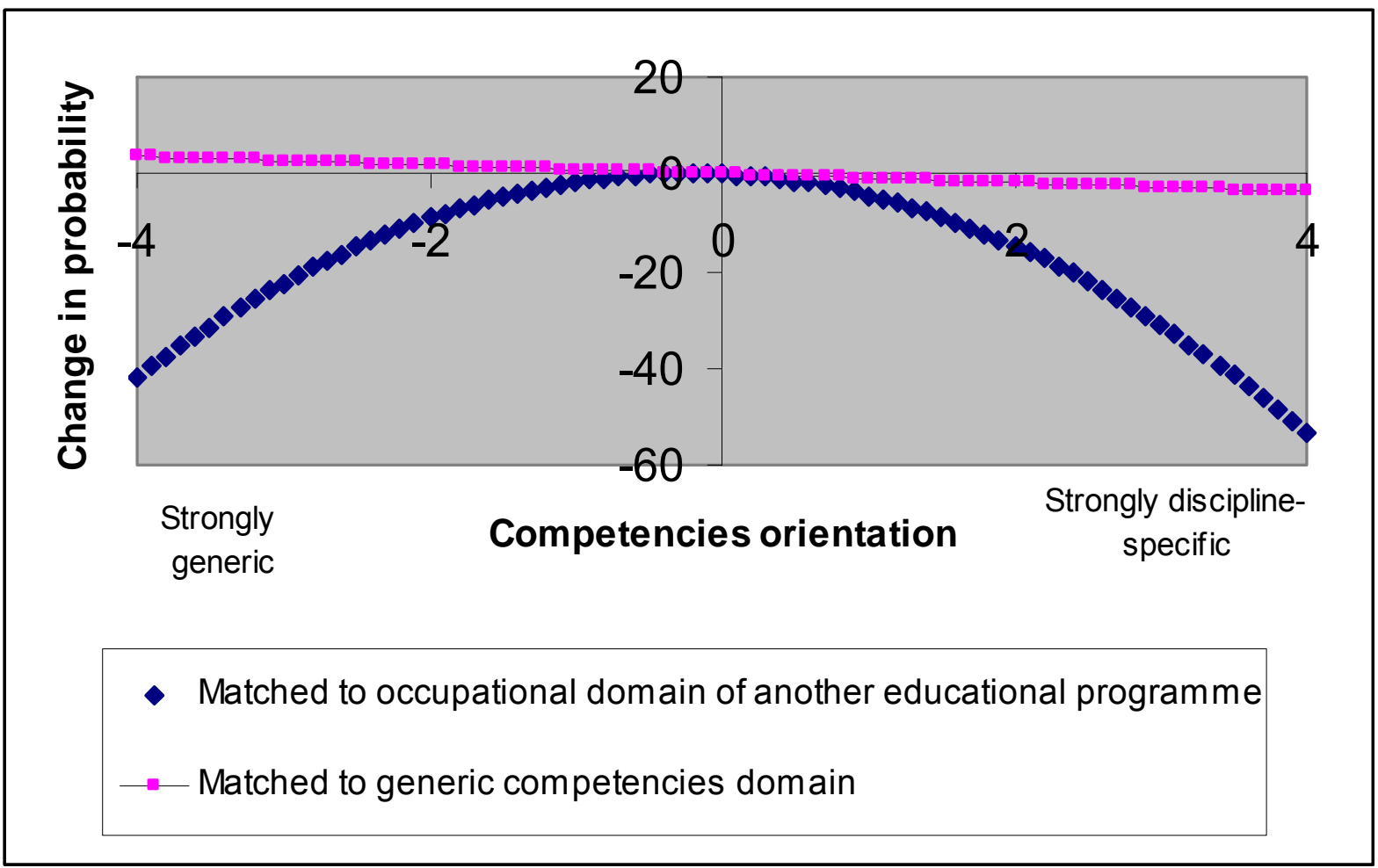

Note: The figures were drawn for the full possible range of competence orientation $(-4$ to +4$)$

The reader should bear in mind that the programmes under consideration have a range from -0.70 to +0.38

Combining the results presented in Table 2 and Table 3, we may conclude the following (see Figure 1). Graduates from highly academically oriented programmes are most likely to be matched to an occupation inside the academic competencies domain. Moving from the left to the centre, and hence towards programmes providing a balanced competencies approach, the probability of being matched inside the academic competencies domain relative to the own discipline-specific competencies domain is reduced. At the same time, the relative probability of being matched to an occupation in the domain of another education programme increases. Hence, graduates from balanced education programmes most likely have to accept an occupation in the domain in which neither their discipline-specific competencies nor their academic competencies are regarded as central. Lastly, moving further to highly discipline-specifically oriented programmes, we can see that both the relative probability of being matched to an occupation in the academic competencies domain and the relative probability of being matched to an occupation in the domain of another education programme is reduced. Hence, the allocation outcome seems to be very much in line with the implications of a comparative advantage approach. Graduates are matched, when possible, to activities that make use of the acquired competencies on a large scale. Moreover, the results indicate that if the labour market, as is often argued, is shifting towards academic competencies, programmes offering a highly discipline-specific competencies education need to change their programmes considerably, in order to avoid that their 
graduates have to accept occupations in which neither their type of discipline-specific competencies nor their academic competencies are valued highest.

Taking stock at the end of our first result section, we may conclude the following. The only two programme characteristics of real relevance for the allocation outcome of the graduates are the boundaries around the health and law sectors and the competence orientation of the education programme they followed. However, we would like to remind the reader that the first-stage results presented in Appendix B indicate that both participation in an internship or work placement and spending some time abroad during one's study, influence the allocation outcome of an individual graduate. In other words, the nonsignificance of these indicators in the second stage indicates that there are no spillover effects on the non-participating peers.

\subsubsection{Wages}

Analogously to the discussion on the allocation outcome, we will present the results of the second-stage wage analyses step by step. ${ }^{14}$ We will start with the wages paid to graduates working inside the own discipline-specific domain, followed by a discussion of the findings for graduates working in the discipline-specific domain of another education programme and lastly, we will have a closer look at the wages paid to graduates working in the academic competencies domain. A point to be taken into account during the discussion of the results is the fact that graduates working inside the discipline-specific competencies domain of another education programme (the academic competencies domain) on average earn approximately $11 \%(4 \%)$ less than graduates working inside the own discipline-specific competencies domain.

Table 4

Impact on wages when working inside one's own domain (standard errors in brackets)

\begin{tabular}{|c|c|c|c|c|c|c|c|c|c|}
\hline & \multicolumn{9}{|c|}{ Model } \\
\hline & 0 & 1 & 2 & 3 & 4 & 5 & 6 & 7 & 8 \\
\hline Discipline-specific & & -0.02 & -0.05 & & & & & & 0.03 \\
\hline orientation & & $(0.07)$ & $(0.07)$ & & & & & & $(0.09)$ \\
\hline (Discipline-specific & & & -0.26 & & & & & & -0.13 \\
\hline${\text { orientation })^{2}}^{2}$ & & & $(0.18)$ & & & & & & $(0.20)$ \\
\hline Standardization of & & & & $0.28^{\star *}$ & & & & & $0.18^{*}$ \\
\hline discipline-specific & & & & $(0.11)$ & & & & & $(0.10)$ \\
\hline competencies & & & & & & & & & \\
\hline Standardization of & & & & & 0.24 & & & & 0.13 \\
\hline academic competencies & & & & & $(0.16)$ & & & & $(0.19)$ \\
\hline Work-Learning & & & & & & -0.001 & & & -0.001 \\
\hline & & & & & & $(0.001)$ & & & $(0.001)$ \\
\hline Abroad & & & & & & & 0.06 & & 0.10 \\
\hline & & & & & & & $(0.13)$ & & $(0.13)$ \\
\hline Dummy for law and & & & & & & & & $-0.04^{* *}$ & -0.02 \\
\hline health sciences & & & & & & & & $(0.02)$ & $(0.03)$ \\
\hline
\end{tabular}

14. Appendix $B$ reports on the first-stage estimation findings and the fixed effects extracted. 


\begin{tabular}{|c|c|c|c|c|c|c|c|c|c|}
\hline & & \multicolumn{8}{|c|}{ Model } \\
\hline & 0 & 1 & 2 & 3 & 4 & 5 & 6 & 7 & 8 \\
\hline $\begin{array}{l}\text { Institutions dummies } \\
\text { included }\end{array}$ & YES & YES & YES & YES & YES & YES & YES & YES & YES \\
\hline Adj. $R^{2}$ & 0.90 & 0.90 & 0.90 & 0.91 & 0.90 & 0.90 & 0.90 & 0.90 & 0.91 \\
\hline $\mathrm{N}$-cases & 91 & 91 & 91 & 91 & 91 & 91 & 91 & 91 & 91 \\
\hline
\end{tabular}

Note 1: All models further include an unrestricted constant and were estimated using WLS with the inverse sampling variance as weight

Note 2: ${ }^{* * *}$ significant at $1 \%$ level, ${ }^{* *}$ significant at $5 \%$ level, ${ }^{*}$ significant at $10 \%$ level

We will start by discussing a number of estimation models (Table 4) fitted to the estimated wage differentials between graduates of different education programmes, all working inside their own discipline-specific domain. Including the characteristics individually first (Models 1 through 7) results in the outcome that two characteristics reveal a significant influence on the wage rate. First, and in line with the expectations, we found that graduates from more standardized discipline-specific programmes on average receive higher wages. Second, we found that graduates from law and health faculties on average start with lower wages. No significant impact was found for the other characteristics, namely the disciplinespecific orientation, the standardization of academic competencies, the work-learning relation and internationalization. Entered jointly, the negative impact of the dummy for law and health graduates is no longer significant, whereas the result with respect to the standardization of the discipline-specific competencies does not change qualitatively.

\begin{tabular}{|c|c|c|c|c|c|c|c|c|c|}
\hline & 0 & 1 & 2 & 3 & $\begin{array}{l}\text { Model } \\
4\end{array}$ & 5 & 6 & 7 & 8 \\
\hline $\begin{array}{l}\text { Discipline-specific } \\
\text { orientation }\end{array}$ & & $\begin{array}{l}-0.03 \\
(0.12)\end{array}$ & $\begin{array}{l}-0.10 \\
(0.14)\end{array}$ & & & & & & $\begin{array}{l}-0.05 \\
(0.14)\end{array}$ \\
\hline $\begin{array}{l}\text { (Discipline-specific } \\
\text { orientation) }^{2}\end{array}$ & & & $\begin{array}{l}-0.36 \\
(0.38)\end{array}$ & & & & & & $\begin{array}{l}-0.28 \\
(0.36)\end{array}$ \\
\hline $\begin{array}{l}\text { Standardization of } \\
\text { discipline-specific } \\
\text { competencies }\end{array}$ & & & & $\begin{array}{l}0.29 \\
(0.231)\end{array}$ & & & & & $\begin{array}{l}0.24 \\
(0.17)\end{array}$ \\
\hline $\begin{array}{l}\text { Standardization of } \\
\text { academic competencies }\end{array}$ & & & & & $\begin{array}{l}0.65^{\star * *} \\
(0.22)\end{array}$ & & & & $\begin{array}{r}0.45^{*} \\
(0.26)\end{array}$ \\
\hline Work-Learning & & & & & & $\begin{array}{l}-0.001 \\
(0.001)\end{array}$ & & & $\begin{array}{l}-0.001 \\
(0.001)\end{array}$ \\
\hline Abroad & & & & & & & $\begin{array}{l}-0.23 \\
(0.19)\end{array}$ & & $\begin{array}{l}-0.18 \\
(0.19)\end{array}$ \\
\hline
\end{tabular}




\begin{tabular}{|c|c|c|c|c|c|c|c|c|c|}
\hline & \multicolumn{9}{|c|}{ Model } \\
\hline & 0 & 1 & 2 & 3 & 4 & 5 & 6 & 7 & 8 \\
\hline $\begin{array}{l}\text { Dummy for law and } \\
\text { health sciences }\end{array}$ & & & & & & & & $\begin{array}{l}-0.06 \\
(0.04)\end{array}$ & $\begin{array}{l}-0.03 \\
(0.04)\end{array}$ \\
\hline $\begin{array}{l}\text { Institutions dummies } \\
\text { included }\end{array}$ & YES & YES & YES & YES & YES & YES & YES & YES & YES \\
\hline Adj. $R^{2}$ & 0.83 & 0.84 & 0.84 & 0.84 & 0.88 & 0.83 & 0.82 & 0.82 & 0.88 \\
\hline $\mathrm{N}$-cases & 82 & 82 & 82 & 82 & 82 & 82 & 82 & 82 & 82 \\
\hline
\end{tabular}

Note 1: All models further include an unrestricted constant and were estimated using WLS with the inverse sampling variance as weight

Note 2: ${ }^{* * *}$ significant at $1 \%$ level, ${ }^{* *}$ significant at $5 \%$ level, * significant at $10 \%$ level

Table 5 reports on a series of models fitted to the estimated wage differentials between graduates of different education programmes, all working in the domain of another education programme. Entering the characteristics in a first step individually reveals the significant importance of one characteristic. We found that the standardization of academic competencies now takes over the role of the standardization of discipline-specific competencies in the estimations above. Hence, employers accepting graduates from education programmes not directly linked to the discipline-specific competencies of the occupation, profit from an increased standardization of academic competencies, which they at least partially transfer to the employee in the form of higher wages. No significant impact was found for the discipline-specific competence orientation of the programme, worklearning interrelation, the internationalization of the programme, or the dummy for the studies of law and health sciences. When entered jointly, the individual impact of the standardization with respect to academic competencies did not change qualitatively.

Lastly, turning to a series of models (Table 6) fitted to the estimated wage differentials for graduates working in the academic domain, we found that the standardization of the academic competencies, as in the case above, again played a significant role in the determination of wage rates. Furthermore, when entered individually, the standardization of discipline-specific competencies also showed a significant impact. However, the individual impact of the academic competencies standardization was roughly twice as large as the impact of the standardization with respect to discipline-specific competencies. When entered jointly, the correlation between the two standardization measures, together with the fact that they both individually showed a slightly positive correlation with the wage rate, resulted in a loss of significance for both characteristics. ${ }^{15}$ Comparing the results of Table 6 with the findings in Tables 4 and 5, we can see that the impact of the standardization of disciplinespecific competencies, when taken individually, is smaller than inside the own disciplinespecific competencies domain and that the same holds for the standardization of the academic competencies when compared to the results inside the discipline-specific

15. Inserting in Model 8 both the other characteristics and only one of the standardization measures, does not qualitatively change the results presented in Models 3 and 4. 
competencies domain of another educational domain. None of the other characteristics showed an impact on the graduates' wages in the academic competencies domain, either individually or when entered jointly.

Table 6

Impact on wages when working in academic domain (standard errors in brackets)

\begin{tabular}{|c|c|c|c|c|c|c|c|c|c|}
\hline & \multicolumn{9}{|c|}{ Model } \\
\hline & 0 & 1 & 2 & 3 & 4 & 5 & 6 & 7 & 8 \\
\hline Discipline-specific & & 0.02 & -0.06 & & & & & & 0.01 \\
\hline orientation & & $(0.13)$ & $(0.15)$ & & & & & & $(0.16)$ \\
\hline (Discipline-specific & & & -0.34 & & & & & & -0.34 \\
\hline${\text { orientation })^{2}}^{2}$ & & & $(0.31)$ & & & & & & $(0.21)$ \\
\hline Standardization of & & & & $0.21^{*}$ & & & & & 0.04 \\
\hline discipline-specific & & & & $(0.13)$ & & & & & $(0.21)$ \\
\hline competencies & & & & & & & & & \\
\hline Standardization of & & & & & $0.47^{*}$ & & & & 0.46 \\
\hline academic competencies & & & & & $(0.26)$ & & & & $(0.30)$ \\
\hline Work-Learning & & & & & & -0.001 & & & -0.001 \\
\hline & & & & & & $(0.001)$ & & & $(0.001)$ \\
\hline Abroad & & & & & & & 0.05 & & -0.33 \\
\hline & & & & & & & $(0.21)$ & & $(0.22)$ \\
\hline Dummy for law and health & & & & & & & & -0.02 & 0.00 \\
\hline sciences & & & & & & & & $(0.04)$ & $(0.05)$ \\
\hline $\begin{array}{l}\text { Institutions dummies } \\
\text { included }\end{array}$ & YES & YES & YES & YES & YES & YES & YES & YES & YES \\
\hline Adj. $R^{2}$ & 0.91 & 0.91 & 0.91 & 0.91 & 0.92 & 0.91 & 0.91 & 0.91 & 0.92 \\
\hline $\mathrm{N}$-cases & 86 & 86 & 86 & 86 & 86 & 86 & 86 & 86 & 86 \\
\hline
\end{tabular}

Note 1: All models also include an unrestricted constant and higher education institution dummies and were estimated using WLS with inverse sampling variance as weight

Note 2: ${ }^{* * *}$ significant at $1 \%$ level, ${ }^{* *}$ significant at $5 \%$ level, ${ }^{*}$ significant at $10 \%$ level

Taking stock at the end of this discussion on wage results, the following picture emerges. We proposed that standardizing the competencies outcome of students is a way in which an education programme may help improve the information provided to potential employers. These results confirm this.

Considering the competence orientation of the programme, we expected graduates from discipline-specifically oriented programmes to lose considerably in terms of competencies applicability when not matched to an occupation inside the own discipline-specific competencies domain. The findings did not confirm this hypothesis. However, the reader should bear in mind that competence orientation played a significant role in the allocation process and that the allocation outcome influences the average wages. Graduates working inside the own educational domain on average were paid highest, followed by graduates working in the academic competencies domain and graduates in the domain of another education programme.

With respect to the characteristics that measure how international an education programme is or how strongly it combines learning with working, we could not establish any 
positive spillover effects. However, we need to bear in mind that in two out of the three domains, spending some time abroad during the study period increases the wage rate on an individual level (see Appendix B). Lastly, we did not find any evidence that graduates from the two special studies of law and health sciences were penalised extra when matched outside their highly regulated own educational domain. However, these graduates were more likely to find an occupation inside their own education domain.

\section{Concluding remarks}

The objective of this paper was to investigate to what extent specific characteristics of higher education programmes influenced the transition of graduates to working life. Key elements were the effectiveness of programmes in allocating graduates across various occupational domains and how graduates performed in the occupations they obtained.

We showed that programmes providing a highly discipline-specifically oriented outcome were most likely to place their graduates in the occupational domain with a related type of competencies. Similarly, programmes providing a highly academically oriented outcome placed their graduates in the academic competence domain. Independently of the country concerned, the results confirmed the strong reflection of the competence requirements on the labour market in the outcome of higher education programmes. So far so good. But the analyses also showed that graduates from programmes attempting a balanced mix in the competence outcome, were most likely to have to accept a lower-paying occupation, neither valuing their type of discipline-specific nor their academic competencies properly. This result indicates in particular a clear danger for programme designers in traditional discipline-specifically oriented countries. If the labour markets in these countries, as is often claimed, are changing gradually to a more academic-competence-oriented one, creating upward pressure for the demand and wages of higher education graduates in the academic competence domain, higher education programmes need to make a drastic adjustment with regard to the central competencies in their programmes.

The second result is that it is not enough for a programme to focus on a particular type of competence (academic or discipline-specific), but programmes must also produce a group of graduates that is highly harmonized with respect to this type of competence. In particular, standardization of discipline-specific competencies provides the employers with better information on the actual productive capabilities of the graduates if they are matched to an occupation insider their own discipline-specific competencies domain. Standardization of academic competencies is in particular helpful in case graduates are matched to an occupation in the domain of another education programme as it provides more insight in the graduate's learning abilities. In both cases, standardization can reduce selection and adjustment costs and allows for higher remuneration.

\section{References}

Acemoglu, D., J.-S. Pischke (1998), Why do firms train? Theory and evidence, The Quarterly Journal of Economics, 113 (1), pp. 79- 119. 
Allmendinger, J. (1988), Career Mobility Dynamics. A Comparative Analysis of the United States, Norway and West Germany, Thesis, Cambridge Massachusetts: Harvard University.

Ashton, D., F.Green (1996), Education, training and the global economy, Edward Elgar, Cheltenham.

Barron, J.M., M.A. Loewenstein (1985), On employer specific information and internal labor markets, Southern Economic Journal, 52, 431-445.

Berger, M.C. (1988a), Predicted future earnings and choice of college major, Industrial and Labour Relations Review, 41(3), 418-429.

Berger, M.C. (1988b), Cohort size effects on earnings: differences by college major, Economics of Educational Review, 7, 375-383.

Becker, G.S. (1964), Human Capital: a theoretical and empirical analysis with special reference to education, New York: NBER.

Brown, J. (1989), Why do wages increase with tenure? On the job training and life cycle wage growth observed within firms, American Economic Review, 79, pp. 971-991.

Card, D., A. Krueger (1992), Does School Quality Matter? The Journal of Political Economy, 100 (1), $1-40$.

Case, A., M. Yogo (1999), Does School Quality Matter? Returns to Education and the Characteristics of Schools in South Africa, NBER Working Paper No, 7399, New York: NBER.

Finnie, R., M. Frenette (2003), Earning differences by major field of study: evidence from three cohorts of recent Canadian graduates, Economics of Education Review, 22, 179-192.

Hannan, D., D. Raffe., E. Smyth (1996), Cross-National Research on School to Work Transitions: An Analytic Framework, Paper presented at the 1996 Workshop of the Network Transitions in Youth, September, La Ciotat.

Heckman, J., A. Layne-Farra, P. Todd (1996), Human capital pricing equations with an application to estimating the effect of schooling quality on earnings, The Review of Economics and Statistics, $78,562-610$.

Heijke, H., C.Meng, C.Ris (2003), Fitting to the job: the role of generic and vocational competencies in adjustment and performance, Labour Economics, 10 (2003), 215-229.

Hövels, B. (2003), The Knowledge Economy: learning and work integrated, Preparatory background paper for the 2003 WACE conference in Rotterdam.

James, E., N. Alsalam, J.C. Conaty, D. L.L. To (1989), College quality and future earnings: where should you send your child to college?, American Economic Review, 79, 247-252.

Jovanovic, B. (1979), Job matching and the theory of turnover, Journal of Political Economy, 87, $1246-1260$.

Jovanovic, B. (1984), Matching, turnover and unemployment, Journal of Political Economy, 92, 108122.

Kessels, J. W. M. (1998). Opleiden in een kenniseconomie. [Education in a knowledge economy] In: B. van Gent, \& H. J. M. van der Zee, (eds.), Competentie en arbeidsmarkt. Een multidisciplinaire visie op ontwikkelingen rond mens en werk, Den Haag: Elsevier Bedrijfsinformatie, 75-81. 
Kessels, J.W.M., P. van Wijngaarden (2003), A competency-BAsed approach to cooperative education in the university curriculum, Paper presented at the 2003 WACE conference in Rotterdam.

Kim, A., K-W. Kim (2002), Returns to Tertiary Education in Germany and the UK: Effects of Fields of Study and Gender, Working Paper 62, Mannheimer Zentrum für Europäische Sozialforschung, University of Mannheim.

Lazaear, E.P. (2003), Firm-specific human capital: a skills-weight approach, IZA discussion paper no. 813, Bonn: IZA.

Lynch, L. (1992), Private sector training and earnings of young workers, American Economic Review, 82, pp. 299-312.

Maurice, M., F. Sellier, J.J. Sylvestre (1982), Politique d'éducation et organisation industrielle en France et en Allemagne, Paris : Presses Universitaires de France.

Meng, C. (2006), Discipline-Specific or Academic? Acquistion, Role and Value of Higher Education Competencies, ROA Dissertation Series, ROA: Maastricht.

Mincer, J. (1974), Schooling, Experience and Earnings, New York: Columbia University Press.

Moulton, B. (1986), Random Group Effects and the Precision of Regression Estimates, Journal of Econometrics, 32 (2), 385-397.

Müller, W., S. Steinmann, R. Ell (1998), Education and labour market entry in Germany, in: Shavit, Y., Müller, W. (eds) From School to Work: A comparative study of educational qualifications and occupational destinations, Oxford: Clarendon Press, 143-188.

Müller, W., Y. Shavit (1998), The Institutional Embeddedness of the Stratification Process: A Comparative Study of Qualifications and Occupations in Thirteen Countries, In: Shavit, Y. \& W. Müller (1998), From School to Work. A Comparative Study of Educational Qualifications and Occupational Destinations, Oxford: Clarendon Press, 1-48.

Pischke, J.-S. (2000), Continuous training in Germany, IZA Discussion Paper, vol. 137., Bonn: IZA.

Rumberger, R.W., S.L. Thomas (1993), The economic returns to college major, quality and performance: A multilevel analysis of recent graduates, Education of Economics Review, 12 (1), $1-19$.

Spence, A. (1973), Job Market Signaling, The Quarterly Journal of Economics, vol. 87(3), 355-74.

Topel, R. (1986), Job mobility, search and earnings growth, Research in Labor Economics 8, 199233.

Werfhorst, H.G.van de (2002), Fields of study, acquired skills and the wage benefit from a matching job, ACTA Sociologica, 45, pp. 287-303. 



\section{Appendix A: Education programme characteristics}

Table A.1

Discipline-specific competence orientation

\begin{tabular}{|c|c|c|c|c|c|c|c|}
\hline & $A H$ & SS & $B U$ & $L A$ & $N S$ & $E N$ & $H E$ \\
\hline ITU & -.21 & -0.38 & -0.30 & -0.46 & -0.16 & -0.22 & -0.40 \\
\hline ESU & -0.09 & -0.34 & -0.12 & -0.34 & -0.05 & -0.30 & 0.07 \\
\hline FRU & -0.15 & -0.24 & -0.23 & -0.22 & -0.18 & -0.29 & N.A. \\
\hline FRGE & N.A. & N.A. & -0.54 & N.A. & -0.30 & -0.58 & N.A. \\
\hline ATU & 0.02 & -0.10 & 0.11 & -0.04 & 0.15 & 0.19 & 0.38 \\
\hline DU & 0.14 & 0.14 & 0.10 & 0.16 & 0.15 & 0.10 & 0.02 \\
\hline DFH & 0.09 & N.A. & 0.27 & 0.23 & -0.11 & 0.07 & 0.14 \\
\hline NLU & -0.06 & 0.15 & 0.07 & -0.21 & 0.06 & 0.15 & 0.11 \\
\hline NLHBO & 0.17 & 0.16 & 0.04 & N.A. & 0.15 & 0.05 & 0.13 \\
\hline UKU & -0.34 & -0.41 & -0.46 & -0.70 & -0.20 & -0.30 & 0.22 \\
\hline UKNU & -0.25 & -0.39 & -0.38 & -0.54 & -0.34 & -0.24 & 0.13 \\
\hline FIU & 0.06 & -0.10 & -0.17 & -0.23 & 0.00 & -0.07 & 0.20 \\
\hline NOU & 0.10 & 0.10 & -0.32 & 0.38 & 0.19 & 0.04 & 0.34 \\
\hline NOC & 0.23 & 0.37 & 0.03 & & 0.00 & -0.069 & 0.10 \\
\hline
\end{tabular}

Note: Measured as (average of discipline-specific competencies) - (average of academic competencies) N.A.:not available; ITU = Italian universities, ESU= Spanish universities, FRU = French universities, FRGE $=$ French Grande Écoles, ATU $=$ Austrian universities, $\mathrm{DU}=$ German universities, DFH = German Fachhochschulen, NLU $=$ Dutch universities, NLHBO $=$ Dutch higher vocational institutes, UKU $=$ United Kingdom old universities, UKNU = United Kingdom new universities, FIU = Finish universities, NOU = Norwegian universities, NOC = Norwegian university colleges, $\mathrm{AH}=$ Arts and Humanities, $\mathrm{SS}=$ Social Sciences, $\mathrm{BU}=$ Business, $\mathrm{LA}=$ Law, NS $=$ Natural Sciences, $\mathrm{EN}=$ Engineering, $\mathrm{HE}=$ Health Sciences

Table A2a

Standardization of discipline-specific competencies

\begin{tabular}{lccccccc}
\hline & $A H$ & $S S$ & $B U$ & $L A$ & $N S$ & $E N$ & $H E$ \\
& & & & & & & \\
\hline ITU & 1.05 & 0.66 & 0.67 & 1.11 & 0.76 & 0.66 & 0.85 \\
ESU & 0.77 & 0.67 & 0.66 & 0.66 & 0.68 & 0.74 & 0.72 \\
FRU & 0.79 & 0.66 & 0.54 & 0.90 & 0.70 & 0.78 & N.A. \\
FRGE & N.A. & N.A. & 0.60 & N.A. & 0.52 & 0.59 & N.A. \\
ATU & 0.65 & 0.64 & 0.51 & 0.70 & 0.57 & 0.48 & 0.64 \\
DU & 0.55 & 0.59 & 0.63 & 0.63 & 0.51 & 0.53 & 0.74 \\
DFH & 0.64 & N.A. & 0.62 & 0.80 & 0.76 & 0.48 & 0.51 \\
NLU & 0.54 & 0.70 & 0.60 & 0.46 & 0.53 & 0.41 & 0.68 \\
NLHBO & 0.61 & 0.58 & 0.65 & N.A. & 0.60 & 0.49 & 0.56 \\
UKU & 1.15 & 0.92 & 0.94 & 0.97 & 0.95 & 1.07 & 0.99 \\
UKNU & 0.99 & 0.79 & 0.85 & 0.90 & 0.97 & 0.75 & 0.79 \\
FIU & 0.60 & 0.56 & 0.52 & 0.54 & 0.66 & 0.60 & 0.59 \\
NOU & 0.64 & 0.49 & 0.40 & 0.64 & 0.52 & 0.60 & 0.49 \\
NOC & 0.53 & 0.51 & 0.49 & N.A. & 0.32 & 0.59 & 0.54 \\
& & & & & & & \\
\hline NOS: Meas & & & & & & & \\
\end{tabular}

Note: Measured as within variance of discipline-specific competencies; N.A.: not available 


\begin{tabular}{lccccccc}
\hline & $A H$ & $S S$ & $B U$ & $L A$ & $N S$ & $E N$ & $H E$ \\
& & & & & & & \\
\hline ITU & 0.36 & 0.40 & 0.36 & 0.48 & 0.40 & 0.40 & 0.44 \\
ESU & 0.57 & 0.40 & 0.42 & 0.49 & 0.41 & 0.42 & 0.48 \\
FRU & 0.43 & 0.45 & 0.32 & 0.45 & 0.41 & 0.41 & N.A. \\
FRGE & N.A. & N.A. & 0.32 & N.A. & 0.30 & 0.26 & N.A. \\
ATU & 0.40 & 0.36 & 0.40 & 0.44 & 0.29 & 0.35 & 0.45 \\
DU & 0.40 & 0.38 & 0.32 & 0.33 & 0.33 & 0.27 & 0.47 \\
DFH & 0.56 & N.A. & 0.38 & 0.34 & 0.14 & 0.35 & 0.27 \\
NLU & 0.37 & 0.32 & 0.25 & 0.27 & 0.03 & 0.26 & 0.34 \\
NLHBO & 0.39 & 0.42 & 0.28 & N.A. & 0.39 & 0.26 & 0.29 \\
UKU & 0.46 & 0.37 & 0.31 & 0.35 & 0.35 & 0.38 & 0.48 \\
UKNU & 0.50 & 0.29 & 0.32 & 0.32 & 0.45 & 0.47 & 0.47 \\
FIU & 0.37 & 0.39 & 0.35 & 0.34 & 0.38 & 0.34 & 0.39 \\
NOU & 0.35 & 0.30 & 0.28 & 0.30 & 0.33 & 0.35 & 0.38 \\
NOC & 0.42 & 0.33 & 0.26 & & 0.22 & 0.34 & 0.37 \\
& & & & & & & \\
\hline NOt: & & & & & & & \\
\end{tabular}

Note: Measured as within variance of academic competencies; N.A.: not available

Table A3

Work-learning relation

\begin{tabular}{|c|c|c|c|c|c|c|c|}
\hline & $A H$ & SS & $B U$ & $L A$ & $N S$ & $E N$ & $H E$ \\
\hline ITU & 3 & 7 & 8 & 1 & 5 & 14 & 14 \\
\hline ESU & 41 & 38 & 24 & 7 & 19 & 30 & 51 \\
\hline FRU & 23 & 37 & 69 & 28 & 48 & 69 & N.A. \\
\hline FRGE & N.A. & N.A. & 86 & N.A. & 91 & 92 & N.A. \\
\hline ATU & 27 & 36 & 20 & 7 & 17 & 25 & 65 \\
\hline DU & 57 & 59 & 45 & 67 & 40 & 73 & 77 \\
\hline DFH & 47 & N.A. & 45 & 78 & 77 & 47 & 71 \\
\hline NLU & 57 & 67 & 68 & 46 & 63 & 74 & 52 \\
\hline NLHBO & 57 & 87 & 82 & N.A. & 81 & 81 & 77 \\
\hline UKU & 18 & 16 & 35 & 7 & 15 & 34 & 56 \\
\hline UKNU & 23 & 19 & 34 & 7 & 35 & 43 & 52 \\
\hline FIU & 31 & 51 & 14 & 5 & 27 & 46 & 44 \\
\hline NOU & 17 & 14 & 23 & 17 & 9 & 30 & 35 \\
\hline NOC & 58 & 61 & 5 & N.A. & 20 & 19 & 76 \\
\hline
\end{tabular}

Note 1: Measured as the percentage of graduates who participated in an internship (or work placement) as part of their degree courses

Note 2: N.A.: not available 
Table A4

Internationalization

\begin{tabular}{|c|c|c|c|c|c|c|c|}
\hline & $A H$ & SS & $B U$ & $L A$ & $N S$ & $E N$ & $H E$ \\
\hline ITU & 35 & 24 & 24 & 7 & 14 & 17 & 13 \\
\hline ESU & 24 & 17 & 13 & 17 & 13 & 17 & 6 \\
\hline FRU & 25 & 9 & 16 & 15 & 11 & 11 & N.A. \\
\hline FRGE & N.A. & N.A. & 50 & N.A. & 23 & 28 & N.A. \\
\hline ATU & 31 & 23 & 36 & 18 & 17 & 30 & 30 \\
\hline DU & 27 & 23 & 23 & 23 & 19 & 33 & 42 \\
\hline DFH & 20 & N.A. & 12 & 0 & 13 & 10 & 10 \\
\hline NLU & 44 & 37 & 34 & 26 & 741 & 48 & 58 \\
\hline NLHBO & 25 & 12 & 29 & N.A. & 16 & 28 & 11 \\
\hline UKU & 37 & 19 & 28 & 27 & 18 & 21 & 49 \\
\hline UKNU & 21 & 17 & 31 & 14 & 14 & 26 & 14 \\
\hline FIU & 26 & 22 & 36 & 19 & 19 & 31 & 19 \\
\hline NOU & 39 & 34 & 34 & 22 & 25 & 22 & 20 \\
\hline NOC & 10 & 24 & 13 & N.A. & 4 & 9 & 11 \\
\hline
\end{tabular}

Note 1: Measured as the percentage of graduates who completed part of their study programmes abroad

Note 2: N.A.: not available

Table A5

Exclusive entrance

ITU

ESU

FRU

FRGE

ATU

DU

DFH

NLU

NLHBO

UKU

UKNU

FIU

NOU

NOC

Note 1: Measured as the percentage of graduates who studied law or health sciences

Note 2: N.A.: not available 



\section{Appendix B: First-stage model}

\section{a) First-stage estimation of allocation model}

Table B1

Multinomial logit analyses on allocation outcome

Another domain

Coefficient

s.e.

Academic domain

Coefficient

s.e.

\begin{tabular}{lcccc}
\hline & & & & \\
Constant & 0.493 & 0.416 & -0.112 & 0.394 \\
Man & 0.055 & 0.068 & -0.005 & 0.063 \\
Age & 0.000 & 0.007 & 0.004 & 0.007 \\
Low secondary grades & Ref. & & Ref. & 0.079 \\
Medium grades & 0.035 & 0.081 & 0.054 & 0.090 \\
High grades & -0.045 & 0.096 & 0.078 & 0.062 \\
Higher educated parents & $-0.236^{* * *}$ & 0.068 & -0.088 & 0.054 \\
Academic competencies & 0.041 & 0.057 & $0.235^{* * *}$ & 0.037 \\
Discipline-specific & $-0.266^{* * *}$ & 0.040 & $-0.213^{* * *}$ & 0.075 \\
competencies & & & & 0.094 \\
Short internship & -0.097 & 0.080 & -0.064 & 0.083 \\
Long internship & $-0.193^{* *}$ & 0.097 & $0.349^{* * *}$ & 0.083 \\
Short related employment & $-0.366^{* * *}$ & 0.095 & $-0.187^{* *}$ & 0.074 \\
Long related employment & $-0.317^{* * *}$ & 0.086 & $-0.348^{* * *}$ & 0.033 \\
Time spent abroad & $0.161^{* *}$ & 0.079 & 0.017 & 0.036 \\
Adaptability & -0.022 & 0.036 & 0.020 & 0.085 \\
Importance to use own skills & $-0.289^{* * *}$ & 0.040 & $-0.476^{* * *}$ & 0.087 \\
Living with partner & -0.111 & 0.095 & -0.099 & 0.095 \\
Living with parents & -0.060 & 0.095 & -0.032 & 0.023 \\
Living with others & -0.124 & 0.106 & & \\
-Log likelihood & & & & \\
& -8228.95 & & & \\
\hline Note & & & & \\
\hline
\end{tabular}

Note 1: Reference domain: own educational domain

Note 2: The model also includes 92 dummies for the different education programmes

Note $3:{ }^{*}$ significant at $10 \%$ level, ${ }^{* *}$ significant at $5 \%$ level, ${ }^{* * *}$ significant at $1 \%$ level 
Table B2

Log odds: relative probability of being matched to an occupation inside the domain of another education programme to being matched to an occupation inside the own discipline-specific domain

$\begin{array}{lllllll}A H & S S & B U & L A & N S & E N & H E\end{array}$

\begin{tabular}{lrrrrrrr}
\hline & & & & & & & \\
ITU & Ref. & -0.16 & -2.15 & -1.11 & -0.22 & -1.54 & n.e. \\
ESU & -0.04 & -0.57 & -0.86 & -0.11 & -0.30 & -0.18 & -0.68 \\
FRU & -0.04 & 0.04 & -0.51 & -0.53 & 0.12 & 0.47 & n.a. \\
FRGE & n.a. & n.a. & -0.96 & n.a. & -0.33 & -0.37 & n.a. \\
ATU & -0.64 & -0.02 & -1.07 & -0.98 & -0.64 & -0.63 & -2.75 \\
DU & -0.50 & -0.73 & -0.57 & -0.86 & -0.16 & -0.52 & -1.46 \\
DFH & -1.49 & n.e. & -0.96 & -2.01 & -0.44 & 0.00 & -1.88 \\
NLU & 0.60 & 0.22 & -1.14 & -.10 & -0.87 & -0.17 & -2.06 \\
NLHBO & -0.40 & -1.67 & -0.36 & n.a. & -1.80 & -0.53 & -0.87 \\
UKU & -0.38 & 0.16 & -1.46 & n.e. & -0.24 & -0.29 & n.e. \\
UKNU & -0.54 & -0.07 & -0.44 & -1.60 & -0.25 & -0.47 & -1.42 \\
FIU & -0.81 & -0.53 & -1.10 & -1.00 & -0.37 & -0.49 & -2.10 \\
NOU & -0.68 & -1.33 & n.e. & n.e. & -0.82 & -0.39 & n.e. \\
NOC & -3.13 & n.e. & -1.22 & n.a. & n.e. & -1.18 & -2.40
\end{tabular}

Note: $\quad$ N.A.: not available; N.E.: not estimated as no graduates worked in the domain of another programme

Table B3

Log odds: relative probability of being matched to an occupation inside the academic competencies domain to being matched to an occupation inside the own discipline-specific domain

\begin{tabular}{|c|c|c|c|c|c|c|c|}
\hline & $A H$ & SS & $B U$ & $L A$ & $N S$ & $E N$ & $H E$ \\
\hline ITU & Ref. & 0.05 & -0.74 & -0.21 & -0.39 & -1.02 & n.e. \\
\hline ESU & -0.09 & -0.66 & -0.29 & -0.64 & -0.49 & -0.79 & -1.14 \\
\hline FRU & 0.24 & 0.63 & 0.04 & -0.31 & -0.12 & -0.17 & n.a. \\
\hline FRGE & n.a. & n.a. & 0.02 & n.a. & 0.59 & 0.82 & n.a. \\
\hline ATU & 0.38 & 0.46 & 0.75 & -1.03 & -0.09 & 0.47 & -1.62 \\
\hline DU & 0.67 & 0.48 & 0.11 & -1.19 & 0.32 & 0.40 & -1.81 \\
\hline DFH & 0.24 & n.e. & -0.09 & -1.47 & n.e. & -0.37 & -0.34 \\
\hline NLU & 1.30 & 0.72 & 0.28 & -0.43 & -0.38 & 0.39 & -1.69 \\
\hline NLHBO & -0.19 & 0.90 & 0.48 & n.a. & -2.00 & -0.58 & -1.10 \\
\hline UKU & 1.50 & 1.58 & 0.92 & 0.12 & 0.83 & 0.42 & -0.96 \\
\hline UKNU & 0.30 & 1.42 & 1.11 & -0.63 & -0.02 & -0.18 & -0.68 \\
\hline FIU & -1.83 & 0.12 & -0.26 & -1.98 & -0.85 & -0.78 & -3.08 \\
\hline NOU & -0.50 & -0.49 & n.e. & -1.07 & -0.84 & -0.58 & -1.71 \\
\hline NOC & -1.68 & n.e. & -0.65 & n.a. & -1.14 & -0.96 & -1.92 \\
\hline
\end{tabular}

Note: N.A.: not available; N.E.: not estimated as no graduates worked in academic competencies domain 
Table B4

First-stage wage analyses (OLS)

$\begin{array}{llll}\text { Own domain } & \text { Domain of another } & \begin{array}{l}\text { Academic } \\ \text { programme } \\ \text { Coefficient }\end{array} \text { s.e. } & \begin{array}{l}\text { competencies domain } \\ \text { Coefficient s.e. }\end{array}\end{array}$

Constant
Low secondary grades
Medium secondary grade
High secondary grades
Higher educated parents
Man
Age
Short internship
Long internship
Short related employm
Long related employm
Time spent abroad
Discipline-specific comp
Mismatch
Higher education level
required
Lower education level
required
Tenure
Part-time job
Private organization
Training followed
Children
Organization size

Adj. R-squared

$\begin{array}{llllll}2.09^{* * *} & 0.034 & \begin{array}{l}1.99^{* * *} \\ \text { Ref. }\end{array} & 0.124 & \begin{array}{c}2.05^{* * *} \\ \text { Ref. }\end{array} & 0.122 \\ 0.009 & 0.009 & 0.051^{*} & 0.028 & 0.018 & 0.029 \\ 0.016 & 0.010 & 0.060^{*} & 0.033 & -0.012 & 0.033 \\ 0.016^{* *} & 0.007 & 0.005 & 0.024 & -0.006 & 0.023 \\ 0.077^{* * *} & 0.007 & 0.091^{* * *} & 0.024 & 0.048^{* *} & 0.023 \\ 0.005^{* * *} & 0.001 & 0.012^{* * *} & 0.003 & 0.002 & 0.003 \\ -0.010 & 0.008 & -0.019 & 0.028 & -0.030 & 0.028 \\ -0.010 & 0.009 & 0.011 & 0.034 & -0.011 & 0.034 \\ 0.009 & 0.009 & -0.031 & 0.033 & -0.009 & 0.030 \\ 0.033^{* * *} & 0.008 & 0.018 & 0.030 & 0.061^{* *} & 0.030 \\ 0.006 & 0.008 & 0.101^{* * *} & 0.027 & 0.059^{* *} & 0.026 \\ -0.015^{* * *} & 0.003 & 0.007 & 0.007 & 0.013^{*} & 0.007 \\ & & & & & \\ 0.006 & 0.010 & 0.060 & 0.039 & -0.048 & 0.045 \\ & & & & & \\ -0.106^{* * *} & 0.009 & -0.109^{* * *} & 0.024 & -0.182^{* * *} & 0.023 \\ & & & & & \\ 0.001^{* * *} & 0.000 & 0.000 & 0.000 & 0.002^{* * *} & 0.000 \\ 0.162^{* * *} & 0.010 & 0.090^{* *} & 0.038 & -0.081^{* *} & 0.038 \\ 0.025^{* * *} & 0.009 & 0.021 & 0.032 & 0.062^{* *} & 0.030 \\ 0.041^{* * *} & 0.007 & 0.084^{* * *} & 0.024 & 0.011 & 0.023 \\ 0.017^{* *} & 0.008 & -0.014 & 0.030 & 0.069^{* *} & 0.032 \\ -0.000^{* * *} & 0.000 & 0.000^{*} & 0.000 & 0.000 & 0.000 \\ & & & & & \\ 0.40 & & 0.45 & & 0.39 & \end{array}$

Note: All models also include dummies for the education programmes and dummies for 16 different economic sectors

Note: ${ }^{*}$ significant at $10 \%$ level, ${ }^{* *}$ significant at $5 \%$ level, ${ }^{* * *}$ significant at $1 \%$ level 
Fixed-effects rate of returns for graduates working inside the own discipline-specific domain

\begin{tabular}{|c|c|c|c|c|c|c|c|}
\hline & $A H$ & SS & $B U$ & $L A$ & $N S$ & EN & $H E$ \\
\hline ITU & Ref. & 0.14 & 0.22 & 0.10 & 0.05 & 0.19 & -0.10 \\
\hline ESU & -0.06 & -0.08 & -0.25 & -0.13 & -0.05 & 0.04 & -0.17 \\
\hline FRU & 0.38 & 0.30 & 0.32 & 0.26 & 0.44 & 0.39 & n.a. \\
\hline FRGE & n.a. & n.a. & 0.56 & n.a. & 0.65 & 0.54 & n.a. \\
\hline ATU & 0.53 & 0.48 & 0.66 & 0.36 & 0.52 & 0.52 & 0.33 \\
\hline DU & 0.78 & 0.75 & 0.87 & 0.62 & 0.78 & 0.88 & 0.75 \\
\hline DFH & 0.68 & n.a. & 0.69 & 0.49 & 0.83 & 0.80 & 0.57 \\
\hline NLU & 0.37 & 0.49 & 0.58 & 0.55 & 0.46 & 0.53 & 0.54 \\
\hline NLHBO & 0.32 & 0.28 & 0.32 & n.a. & 0.42 & 0.36 & 0.33 \\
\hline UKU & 0.47 & 0.63 & 0.58 & 0.63 & 0.54 & 0.68 & 0.61 \\
\hline UKNU & 0.43 & 0.28 & 0.54 & 0.49 & 0.63 & 0.59 & 0.69 \\
\hline FIU & 0.59 & 0.47 & 0.63 & 0.63 & 0.55 & 0.61 & 0.63 \\
\hline NOU & 0.78 & 0.79 & 0.90 & 0.85 & 0.79 & 0.85 & 0.88 \\
\hline NOC & 0.62 & 0.64 & 0.86 & n.a. & 0.81 & 0.74 & 0.68 \\
\hline
\end{tabular}

Note: N.A.: not available

Table $B 6$

Fixed-effects rate of returns for graduates working inside the domain of another education programme

\begin{tabular}{lrrrrrrr} 
& $A H$ & $S S$ & $B U$ & $L A$ & $N S$ & $E N$ & $H E$ \\
\hline ITU & & & & & & & \\
ESU & Ref. & 0.24 & 0.23 & 0.07 & 0.36 & 0.06 & n.e. \\
FRU & -0.21 & -0.15 & -0.09 & -0.16 & 0.08 & 0.00 & -0.22 \\
FRGE & 0.16 & 0.21 & 0.38 & 0.28 & 0.42 & 0.27 & n.a. \\
ATU & n.a. & n.a. & 0.45 & n.a. & 0.69 & 0.63 & n.a. \\
DU & 0.53 & 0.65 & 0.61 & 0.51 & 0.59 & 0.80 & 0.72 \\
DFH & 0.78 & 0.87 & 0.93 & 0.68 & 0.90 & 0.85 & 0.59 \\
NLU & 0.93 & n.a. & 0.72 & 0.31 & 0.88 & 0.90 & 0.52 \\
NLHBO & 0.41 & 0.44 & 0.37 & 0.72 & 0.41 & 0.44 & 0.37 \\
UKU & 0.27 & 0.31 & 0.32 & n.a. & 0.41 & 0.25 & 0.18 \\
UKNU & 0.61 & 0.47 & 0.66 & n.e. & 0.61 & 0.64 & n.e. \\
FIU & 0.37 & 0.49 & 0.67 & 0.76 & 0.38 & 0.58 & 0.63 \\
NOU & 0.49 & 0.55 & 0.55 & 0.67 & 0.45 & 0.56 & 0.77 \\
NOC & 0.73 & 0.85 & n.e. & n.e. & 0.88 & 0.92 & n.e. \\
& 0.42 & n.e. & 0.87 & n.a. & n.e. & 0.75 & 0.61 \\
\hline NOte: NA.: no. & & & & & & & \\
\hline
\end{tabular}

Note: N.A.: not available; N.E.: not estimated as no graduates worked in the domain of another programme 
Table B7

Fixed-effects rate of returns for graduates working inside the academic competencies domain

\begin{tabular}{|c|c|c|c|c|c|c|c|}
\hline & $A H$ & SS & $B U$ & $L A$ & $N S$ & $E N$ & $H E$ \\
\hline ITU & Ref. & 0.04 & 0.37 & 0.58 & 0.11 & 0.44 & n.e. \\
\hline ESU & -0.16 & 0.12 & 0.02 & 0.08 & -0.07 & 0.26 & 0.02 \\
\hline FRU & 0.49 & 0.57 & 0.51 & 0.57 & 0.57 & 0.65 & n.a. \\
\hline FRGE & n.a. & n.a. & 0.76 & n.a. & 0.94 & 0.81 & n.a. \\
\hline ATU & 0.66 & 0.66 & 0.85 & 0.78 & 0.85 & 0.96 & 0.36 \\
\hline DU & 1.13 & 0.94 & 1.12 & 1.15 & 1.12 & 1.13 & 0.62 \\
\hline DFH & 0.65 & n.a. & 1.02 & 0.71 & n.e. & 1.11 & 0.79 \\
\hline NLU & 0.65 & 0.71 & 0.79 & 0.92 & 0.77 & 0.86 & 0.78 \\
\hline NLHBO & 0.45 & 0.55 & 0.49 & n.a. & 1.19 & 0.61 & 0.53 \\
\hline UKU & 0.80 & 0.79 & 0.84 & 0.36 & 0.78 & 0.73 & 0.69 \\
\hline UKNU & 0.62 & 0.61 & 0.74 & 0.89 & 0.81 & 0.63 & 0.96 \\
\hline FIU & 0.52 & 0.75 & 0.86 & 0.46 & 0.87 & 0.80 & 0.79 \\
\hline NOU & 1.05 & 1.08 & n.e. & 1.17 & 1.02 & 1.17 & 1.19 \\
\hline NOC & 0.97 & n.e. & 1.04 & n.a. & 1.56 & 1.00 & 0.91 \\
\hline
\end{tabular}

Note: N.A.: not available; N.E.: not estimated as no graduates worked in academic competencies domain 



\section{Appendix C: Robustness Tests}

A critical assumption in the first-stage estimations, in which we tried to explain the allocation outcome and wage rate by individual/occupational characteristics and by the dummies for the different education programmes, is the use of fixed-effects models. In this way, we force the covariates to have a homogeneous impact for graduates from different education programmes. This assumption may harm the analyses in cases in which an existing differential impact is at least partially taken over by the education programme dummies that we try to explain in the second stage. To test to what extent the extracted fixed effects of the education programmes are biased by this restriction, we re-estimated the allocation function and wage analyses separately for each of the higher education institutions and then extracted from these analyses the fixed effects for the education programmes. Logically, the first best approach would have been to estimate the allocation function for each education programme in each higher education institution separately. Unfortunately, this approach is not possible, as the number of respondents per education programme is too small, considering they are also allocated over three labour market domains.

Table C1 presents the correlation coefficients between the fixed effects of an education programme when extracted from a pooled estimation with all higher education institutions included ('Extraction 1'), and the fixed effects of an education programme when extracted from estimations separately for each higher education institution ('Extraction 2').

Table C1

Correlations

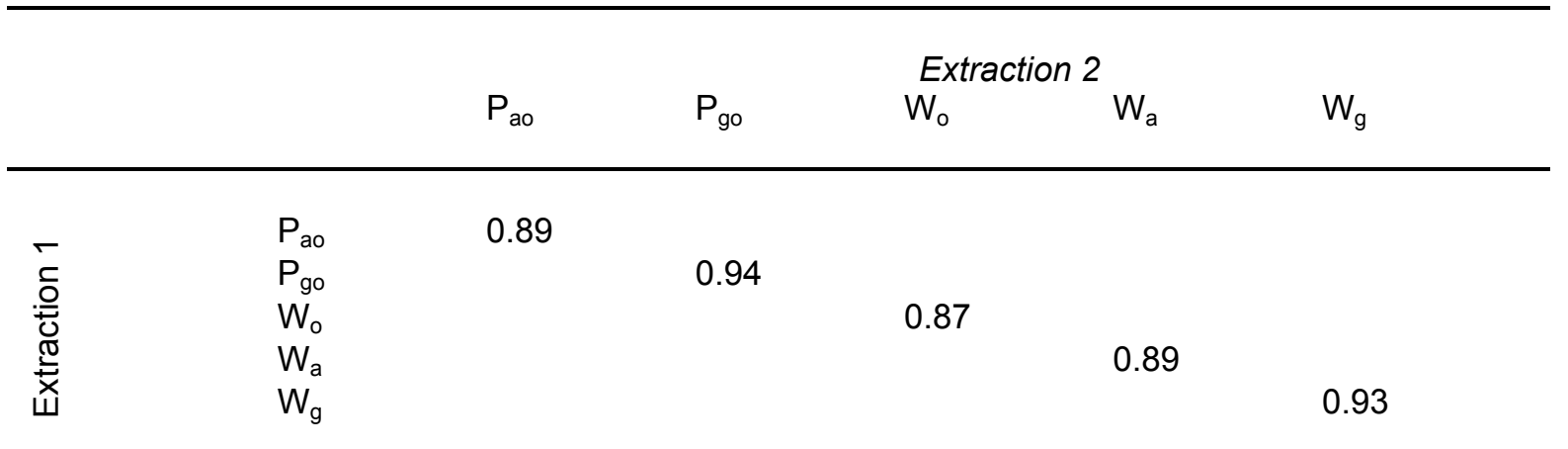

Note: All correlations are significant at a $1 \%$ level

Note: $\mathrm{P}_{\mathrm{ao}}$ : $\quad$ Probability of working inside the domain of another education programme versus

Probability of working inside the own domain

$\mathrm{P}_{\mathrm{go}}$ : Probability of working inside the academic competencies domain versus

Probability of working inside the own domain

$\mathrm{W}_{\mathrm{o}}$ : Wage rate paid to graduates working inside the own domain

$\mathrm{W}_{\mathrm{a}}$ : Wage rate paid to graduates working inside the domain of another educational programme

$\mathrm{W}_{\mathrm{o}}$ : Wage rate paid to graduates working inside the academic competencies domain

In all cases, we can see that the correlations between the fixed effects, as used in this chapter, (Extraction 1) and the fixed effects extracted from first-stage analyses carried out for each higher education institution individually are on a very high level. In other words, although using a fixed-effect model forces the covariates to behave in a homogeneous way over all higher education institutions, this has no real impact on the fixed effects that were extracted and used in the second stage as dependent variables. 